\title{
A critical review of popular technological solutions for climate change as evident in the movie industry
}

\author{
Rajaratnam Shanthini* \\ Department of Chemical \& Process Engineering, Faculty of Engineering, University of Peradeniya, Peradeniya, Sri Lanka.
}

\begin{abstract}
This paper critically reviews four selected movies dealing with climate change and the resulting ecosystem deterioration, namely, The Day After Tomorrow, An Inconvenient Truth, The $11^{\text {th }}$ Hour and The Age of Stupid. It scrutinises the limitations, the hypocrisy and the dilemma embedded in the technological solutions to climate change suggested in the movies, such as reduction in fossil fuel consumption, use of energy efficient technologies and adaptation of renewable energy. The movies' failure to discuss crucial phenomena such as the 'rebound effect' of efficiency improvement technologies, 'well-to-wheel life cycle assessment' of renewable energy technologies, and their power to reverse the capability of chosen technological solutions to combat ecosystem deterioration are highlighted. The review also stresses on the need for movies to place emphasis on moving away not only from egocentrism, as illustrated by reference to selected footages from the movie Amélie, but also from human-centrism towards eco-centrism to save the ecosystem on which all lives depend upon.
\end{abstract}

Keywords: Amélie, An Inconvenient Truth; climate change, energy efficiency, global warming, lifecycle assessment, movie, rebound effect, renewable energy, The $11^{\text {th }}$ Hour, The Age of Stupid, The Day After Tomorrow.

\section{INTRODUCTION}

The movie industry has tasted box-office success as well as critical acclaim with its most selling sustainability genre, which is combating climate change. In this paper, the author critically reviewed four movies dealing with climate change and the consequent ecosystems deterioration, namely, The Day After Tomorrow (Emmerich, 2004), An Inconvenient Truth (Guggenheim, 2006), The $11^{\text {th }}$ Hour (Petersen and Conners, 2007) and The Age of Stupid (Armstrong, 2009). Henceforth, the said movies are referred to as $D A T, I T, 11 H$, and $A S$, respectively.
The controversial topic of climate change and the resulting ecosystem deterioration have been a matter of interest since long ago. The Swedish scientist, Svante August Arrhenius had, in the late $19^{\text {th }}$ century, predicted that increasing atmospheric carbon dioxide $\left(\mathrm{CO}_{2}\right)$ concentration would indeed raise the global surface temperature (Arrhenius, 1896). It was, however, only in the early $21^{\text {st }}$ century that the global forum of Intergovernmental Panel on Climate Change (IPCC) officially announced that the increase in atmospheric concentrations of greenhouse gases, inclusive of the major contributor $\mathrm{CO}_{2}$, would cause the average global surface temperature to rise $1.1^{\circ} \mathrm{C}$ to $6.4^{\circ} \mathrm{C}$ during this century (IPCC, 2007). IPCC also added that such an increase in global surface temperature has the potential to cause irreversible impact on ecosystems. In 2008, when the atmospheric $\mathrm{CO}_{2}$ concentration was 385 parts per million (ppm), Hansen et al. (2008) pointed out that if the planet similar to which life on Earth was adapted, $\mathrm{CO}_{2}$ concentration should be reduced to at most 350 ppm, but likely less than that. They also warned that

"...continued growth of greenhouse gas emissions, for just another decade, practically eliminates the possibility of near-term return of atmospheric composition beneath the tipping level for catastrophic effects" (Hansen et al., 2008).

The atmospheric $\mathrm{CO}_{2}$ concentration, measured at the Mauna Loa Observatory, Hawaii, in December 2014 was, however, 399 ppm (Earth System Research Laboratory, 2015). All these data mean that we live in a critical period in which we must act without delay or perish. All the movies considered in this paper also agree that we do not have the 30 to 40 years that usually take to effect changes in the scale of broad societal mobilisation involving government, industry and communities. This paper is a 
scrutiny of what the movie industry suggested through the movies considered to slow down climate change and to reduce the dreadful impact of climate change upon Mother Earth.

Former Vice President of the United States, Al Gore, whose slide show and personal life experiences pack most of the movie-watching experience of $I T$, states explicitly in $I T$ that he had set a goal to communicate the climate change story very clearly, person by person, with the faith that enough minds would be changed pretty soon, so that we crossed a threshold. Similar sentiments have been expressed by Leonardo DiCaprio in $11 \mathrm{H}$, who is the creator, producer and narrator of $11 \mathrm{H}$, and by the $A S$ team at the Spanner Films website (Spanner Films [online]).

All four movies considered have an underlying tone that it might be hard to save the world from ecosystem destruction resulting from climate change by expecting the political systems and the corporate world to change on their own for the better. It is, therefore, perhaps, they appeal for individualised efforts to slowdown, if not halt, ecosystem damage. They suggest that individual citizens embrace low ecological-footprint lifestyles by adopting energy-efficient technologies and renewable energy technologies. They also appeal to the individuals to exercise their democratic rights to dictate terms on the governments and the corporate worlds to bring about low carbon economies to slow down global warming and to halt climate change.

The underpinning assumption with the makers of the said movies appears to be the following: an informed public would be active in the fight against factors accelerating global warming and climate change. It is, however, found untrue in a survey carried out in the United States by Kellstedt et al. (2008). They found that the respondents who are better informed about the risks of global warming and climate change feel less personally responsible, and also show less concern, for global warming. The survey also found that respondents with high confidence in scientists feel less responsible and show less concern for global warming. These survey results, while seem contrary to the apparent knowledgedeficit model assumptions underlying the movies concerned, are consistent with the findings of Durant and Legge (2005) with respect to genetically modified foods, and with those of Evans and Durant (1995) with respect to embryo research (Kellstedt et al., 2008).

The prime objective of this paper is to analyse the said movies' ability to not only stimulate, but also sustain the public's feeling of personal responsibility and concern for global warming with particular reference to the technological solutions proposed in the movies to combat climate change. The paper highlights the movies' failure to critically examine the different facets of the proposed technological solutions, such as the 'rebound effect' of efficiency improvement technologies (Blake, 2005; Grubb, 1990; Jenkins, 2011; Sorrell, 2007) and the 'well-to-wheel lifecycle assessment' of renewable energy technologies (Dominguez-Faus et al., 2009; Dufour and Iribarren, 2012; Fraiture et al., 2008; Jacobson, 2009). It is to be noted that even though three of the movies considered were released in the wake of the release of the popular, detailed and timely publication titled The Long Emergency: Surviving the Converging Catastrophes of the Twenty-first Century by James Howard Kunstler (2005), the movies failed to discuss or counter the convincing arguments raised by Kunstler in proposing the movies' solutions to slowdown or halt climate change and its induced ecosystems breakdown.

Having scrutinised the technological solutions suggested in the movies, seeking alternatives, this paper probes into the suggestions made in $11 \mathrm{H}$ and $A S$ that the world may better be saved by the magic of kindness, humility, respect and love. Interestingly, these dimensions of humanity are dealt with in greater extent in the critically acclaimed movie Amélie (Jeunet, 2001). References are made to selected footages from Amélie to elucidate the importance of embedding such genres in future movies dealing with ecosystem restoration to reach out for wider audience who could get not only intellectually, but also emotionally, involved in restoring the ecological health of Mother Earth. The crucial role that the emerging concepts such as social equity, ecorights and global justice could play in ecosystem restoration is also briefly discussed.

The rest of the paper is organised as follows: Part 2 gives outlines of the four movies considered for analysis; Part 3 highlights the technological solution to climate change and ecosystem damage told in the movies considered through plot summaries; Part 4 scrutinises the technological solutions proposed in the movies; Part 5 discusses the hypocrisy and dilemma embedded in the movies analysed; Part 6 steps out of the boundaries of the solutions discussed in the movies considered and briefly explores other plausible means of slowing down climate change and ecosystem restoration; Part 7 concludes.

\section{MOVIES ANALYSED}

\section{The Day After Tomorrow (DAT)}

$D A T$ is a hugely popular American movie released in May 2004, and it grossed over half a billion US\$ internationally. DAT appeals to our senses by the specialeffect laden horrors of abrupt change of climate over 
most of northern hemisphere. The story line is based on the probable disastrous consequences of abrupt climate change resulting in the dawn of an ice age, all occurring in a matter of days. Scientific reasons supporting such a fiction-like event are explained in the movie by the lead fictional character, Prof. Jack Hall, as follows:

"The northern hemisphere owes its climate to the North Atlantic Current... Heat from the sun arrives at the equator and is carried north by the ocean... But global warming is melting the polar ice caps and disrupting this flow. Eventually it [North Atlantic Current] will shut down... Cold front moving down from Arctic has created an enormous storm system... The storm's rotation is pulling super cooled air all the way down from the upper troposphere... The basic rule of storms is they continue until the imbalances that created them is corrected... When it is over ice and snow will cover the entire northern hemisphere... The ice and snow will reflect sunlight and the earth's atmosphere will re-stabilize with an average temperature close to that of the last ice age."

The above stated scientific reasoning for the dawn of an ice age, the time scale in which it happened, and the timing of the event have all been challenged in the media. We leave those discussions to the numerous internet sources, and focus only on the implied solutions to combat climate change in $D A T$.

\section{An Inconvenient Truth (IT)}

$I T$ is an American documentary film released in May, 2006, which was two years after the release of DAT. It won an Academy Award for Best Documentary Feature and it is also a box-office success worldwide. The film centres around the impressive slide show of the former United States Vice-President Al Gore and reveals very many striking facts about global warming and climate change. Many scientists have agreed upon the accuracy of the scientific facts retold in the movie except for a few chosen aspects of it (Adam, 2007). Leaving those discussions to the great many internet sources, we focus here on the solutions proposed in $I T$ to combat climate change.

\section{The $11^{\text {th }}$ Hour $(11 \mathrm{H})$}

$11 \mathrm{H}$ is an American documentary film released in May, 2007, almost an year after the release of IT. This film was created and produced by the actor Leonardo DiCaprio, and it deals not only with global warming and climate change but also with all sorts of ailments that the industrial civilisation has inflicted upon Mother Earth. This list includes deforestation, desertification, soil degradation, mass extinction, loss of biodiversity, over fishing, ocean pollution, toxic chemical contamination and more. In $11 \mathrm{H}$, we listen to real-life scientists, environmentalists, ecologists, economists, authors and policy makers about the dreadful status of the biosphere, and probable means to restore its health.

\section{The Age of Stupid (AS)}

$A S$ is a British documentary film released in March, 2009. It is set in year 2055 in a devastated world facing near extinction of the human race. The film opens showing a fictional climate-change-proof global archive located in the ice-less arctic. It is a vast storage structure powered by wind turbines set on its roof, and containing the artwork from every national museum. The film threads a number of real life footages of present time, which show our complacent ways of lives despite the mounting evidence of critical changes in earth's climate.

\section{CLIMATE CHANGE, AS TOLD IN THE MOVIES}

\section{Causes of climate change told}

Prof. Jack Hall, the fictional lead character of DAT, says: "At the rate we are burning fossil fuels and polluting the environment the ice caps would soon disappear." Thereby, a connection between fossil fuel burning and climate change that led to the dawn of the ice age is established in $D A T$. The causal connection among fossil fuel burning, $\mathrm{CO}_{2}$ emissions, global warming and climate change was amply illustrated by the revealing slide show of Al Gore in IT.

Wade Davis, Nathan Gardels, Betsy Taylor and few others interviewed in $11 \mathrm{H}$ look at consumerism, which has gone out of balance, being the cause of the present day climate crisis. Psychologist James Hillman attributes the origins of the consumerist culture to the psychical numbness in human specie caused by noise, by loud music and by light at night. It is because we have lost the feeling of the beauty of the world, James Hillman adds, we are looking for substitutes rushing around, permanently needy and trying to make up for the loss with attempting to conquer, own or possess the world.

Former Senior Economist of the World Bank, Herman Daly, in $11 \mathrm{H}$, stresses that earth systems' deterioration is simply the fundamental opportunity cost of economic growth, since the subsystem economy is set to grow whereas the parent system biosphere remains the same size. Stephen Schneider states that the corporate sector 
today sees economic growth as an end by itself. It fails to see that the economic growth is only a means to attain the end, which is quality of life.

Ray Anderson attributes the waste-making industrial systems being the cause of excessive fossil fuel burning.

Visuals portraying real life experiences in $A S$ offer ample evidence to the above observations on consumerism, greed, corporate power buying out politicians, and economic growth driven environmental deterioration.

\section{Technological solutions advocated}

Prof. Hall of $D A T$ says with reference to the probable onset of climate change induced ice age, "If we don't act soon, our children and grand children will have to pay the price." From the connection Prof. Hall makes between fossil fuel burning and climate change, I deduce that the 'act' Prof. Hall talked of must be 'burning less fossil fuels or emitting less $\mathrm{CO}_{2}$ than what we do today'. Towards the end of DAT, when Prof. Hall was asked about the fate of civilisation in a climate change stricken world, he says,

"Mankind survived the last ice age. We are certainly capable of surviving this one. All depends on whether or not we are able to learn from our mistakes."

Ironically, it is one of those mistakes, the fuel-inefficient, fossil fuel burning, $\mathrm{CO}_{2}$ emitting Black Hawk helicopter (The Black Hawk [online]), rescues Prof. Hall and his group from the snow covered New York to fly them to the warm Mexico.

Al Gore in IT displays gold bars on one side of the balance and the planet Earth on the other side, and he says this prevailing misconception that one ought to choose between the economy and the environment was ill-founded because it was possible to create a lot of wealth and a lot of jobs if we did the right things. By right things, $\mathrm{Al}$ Gore means a list of technological options such as electricity end-use efficiency, other end-use efficiency (not specified), passenger vehicle efficiency, other transport efficiency (not specified), renewable technology, carbon capture and sequestration (CCS) and supply efficiency. Adding the contributions from all the above, $\mathrm{Al}$ Gore shows in $I T$ that the carbon emissions in the United States could be brought below its 1970 level.

Enhancing energy efficiency and subscribing for renewable sources of energy are highly rated also by the intellects interviewed in $11 \mathrm{H}$. The author of The Collapse of Complex Societies, Joseph Tainter, puts it as follows:

"Energy is the key to everything else we do. With an abundant, affordable clean energy we can solve a lot of other problems. Without it we are not going to be able to solve very many problems at all."

Paul Hawken differs from that view and proposes that we need to re-imagine everything we do. William McDonough talks of redesigns in which materials be treated as highly valuable resources and therefore, be processed in cradleto-cradle close-cycle (McDonough and Braungart, 2002) instead of the current cradle-to-grave open-cycle. Other sustainable technological solutions talked about in $11 \mathrm{H}$ include whole system design (Stasinopoulos et al., 2009), biomimicry (Benyus, 2002), waste-free industrial system (Graedel and Allenby, 2003), sustainable building design (Mumovic and Santamouris, 2009), integrated systems that combine housing, feed production, energy generation and waste treatment, diversified transport system replacing automobile-centred transport system, reuse economy replacing throw away economy, polluterpay-system, and more.

\section{Political solutions touched upon}

It is emphasised a few times in DAT that if not for the attitude of the fictional Vice President of the United States, Raymond Becker, millions of lives could have been saved. It is, however, not clearly portrayed what is expected of Becker besides, perhaps, getting his administration to sign the Kyoto Protocol. The real-life former Vice President of the United States, Al Gore, unlike his fictional counterpart Becker, did his best about combating global warming. He was instrumental in introducing carbon tax and in brokering Kyoto Protocol.

Al Gore, however, admits in IT that he failed to get the message across to his colleagues in politics. He also talked of having lost faith in the democratic system. In concluding the slide show in IT, Al Gore quotes from S. Pocala and R. Socolow as follows:

"...humanity already possesses the fundamental scientific, technical and industrial know-how to solve the carbon and climate problems."

Al Gore adds to this quote saying "we have everything we need, save perhaps political will".

In still wanting to fight against climate change, $\mathrm{Al}$ Gore in IT declares that global warming is really not a political issue, and it is a moral issue. Al Gore, as one may 
presume, symbolises the powerlessness of a politician in his/her attempt to create the collective consciousness necessary in restoring the deteriorating biosphere.

Leonardo DiCaprio in $11 \mathrm{H}$ holds a contradictory view. He says that we as citizens, leaders, consumers and voters have the opportunity to help integrate ecology into governmental policy and everyday living standards. Joseph Tainter in $11 \mathrm{H}$, however, dampens the spirit of Leonardo DiCaprio, by his argument that people think in too narrow a scale to address larger problems such as earth systems' deterioration.

\section{SCRUTINY OF THE TECHNOLOGICAL SOLUTIONS TOLD}

\section{Renewable energy as panacea}

In addition to the movies considered lauding renewable energy as a reliable remedy for global warming, $A S$ went one step further to power the screenings of its UK and USA premieres by generating electricity on-site using solar and/or biodiesel originating from waste. $A S$ claims in its website (Spanner Films [online]) that there were zero electricity-related carbon emissions during the production and promotion phases of $A S$. These referred emissions are known as direct emissions, which take into account only the amount of $\mathrm{CO}_{2}$ emitted from the electricity supply during the activity concerned. If one considers the total emissions, including emission stemming from the manufacture and delivery of solar and biodiesel-powered electricity, then the overall picture will be quite different.
Dufour and Iribarren (2012) have calculated the ecological impacts of biodiesel produced from waste vegetable oils (used cooking oil), animal fats (beef tallow and poultry fat) and sewage sludges using the well-to-wheel lifecycle assessment approach. In this approach, the ecological impacts were evaluated considering the electricity production and supply, thermal energy production and supply, water supply, chemicals manufacture and supply and the waste management involved in all stages of the manufacture and transportation of the biodiesel concerned. The results of the said study are reproduced in Table 1 along with the ecological damage potential of low-sulphur diesel originating from fossil fuels.

Table 1 clearly shows that the global warming potentials of biodiesel derived from wastes are far from zero in contrary to what has been reported in the Spanner Films website. They are, in fact, $20-28 \%$ of the global warming potential of the low-sulphur diesel. The cumulative non-renewable energy demands of the waste-based biodiesel are $25-64 \%$ of that of low-sulphur diesel. Eutrophication and photochemical oxidant formation potentials of the biodiesel are more or less of the same magnitudes as those of low-sulphur diesel. The acidification potentials of the biodiesel from beef tallow and poultry fat are considerably larger than that of low-sulphur diesel. It is of interest to note that Lisa Guy claims in $A S$ that her car runs on chick fat, meaning biodiesel produced from poultry fat. It seems obvious that the $A S$ movie team is limited in its knowledge on the alternative energy technologies that they patronise.

Table 1: Ecological damage potentials of diesel fuels of different origins per supply of one GJ of energy evaluated using a well-to-wheels lifecycle analysis

\begin{tabular}{|c|c|c|c|c|c|}
\hline \multirow[b]{2}{*}{ Ecological damage potential } & \multicolumn{5}{|c|}{ Biodiesel from } \\
\hline & $\begin{array}{r}\text { Waste } \\
\text { vegetable oils }\end{array}$ & Beef tallow & Poultry fat & $\begin{array}{l}\text { Sewage } \\
\text { sludges }\end{array}$ & $\begin{array}{r}\text { Low-sulphur } \\
\text { diesel }\end{array}$ \\
\hline $\begin{array}{l}\text { Global warming potential } \\
\left(\mathrm{kg} \mathrm{CO}_{2} \text { eq.) }\right.\end{array}$ & 16.97 & 23.32 & 23.55 & 20.84 & 83.69 \\
\hline $\begin{array}{l}\text { Cumulative non-renewable energy } \\
\text { demand (MJ eq.) }\end{array}$ & 314.3 & 431.8 & 426.8 & 800.0 & 1240.8 \\
\hline $\begin{array}{l}\text { Eutrophication potential } \\
\text { ( } \mathrm{kg} \mathrm{PO}_{4}{ }^{3-} \text { eq.) }\end{array}$ & 0.06 & 0.06 & 0.06 & 0.07 & 0.05 \\
\hline $\begin{array}{l}\text { Photochemical oxidant formation } \\
\text { potential }\left(\mathrm{kg} \mathrm{C}_{2} \mathrm{H}_{4} \text { eq.) }\right.\end{array}$ & 0.01 & 0.01 & 0.01 & 0.01 & 0.01 \\
\hline $\begin{array}{l}\text { Acidification potential } \\
\text { ( } \mathrm{kg} \text { of } \mathrm{SO}_{2} \text { eq.) }\end{array}$ & 0.27 & 0.32 & 0.32 & 0.27 & 0.26 \\
\hline $\begin{array}{l}\text { Ozone layer depletion potential } \\
\text { (mg CFC-11 eq.) }\end{array}$ & 2.04 & 3.08 & 3.14 & 4.14 & 10.7 \\
\hline
\end{tabular}

Source: Dufour and Iribarren (2012) 
However, the most popular renewable source of biodiesel in the United States is soybean; not wastes. Irrigation water requirement of soybean amounts to 14 to 28 million litres per $\mathrm{MWh}$, and that of corn grown for bioethanol amounts to 2 to 8 million litres per MWh (U.S. Department of Energy, 2006). It is ironical that the water requirement of an open-loop-cooling nuclear power plant lies in the range of 95 to 227 thousands litres per MWh, which is the highest water requirement among the conventional fossil and nuclear power plants (Dominguez-Faus et al., 2009). Moreover, Biofuel programmes of India and China are estimated to require 29.7 and $35.1 \mathrm{~km}^{3}$ additional irrigation water in 2030 , respectively, while both countries already face regional and seasonal water shortages (Fraiture et al., 2008).

Paul Hawken of $11 \mathrm{H}$ proposes that energy must come, principally, from the sun. He appears to be correct since the minimum annual global technical potential of solar energy has been estimated as 37,492 million tonnes oil equivalent, which is about three times more than the global primary energy demand in 2008, and 26 times more than the global electricity demand in 2008 (Timilsina et al., 2012). However, there are many barriers to converting the "dilute" solar energy into "concentrated" end-use energy.

Solar photovoltaic electricity generation requires, in addition to space, specially processed materials, such as crystalline silicon, amorphous silicon, cadmium telluride, gallium arsenide or copper indium gallium diselenide. Silicon ( $\mathrm{Si}$ ), the most used photovoltaic material, is produced from silica $\left(\mathrm{SiO}_{2}\right)$, found in high-grade quartz sand, by reacting it with carbon (charcoal) in a furnace operated around $1400^{\circ} \mathrm{C}$. The reaction produces carbon monoxide (CO) gas as follows:

$$
\mathrm{SiO}_{2}+2 \mathrm{C} \rightarrow \mathrm{Si}+2 \mathrm{CO}
$$

Since the molecular masses of $\mathrm{Si}$ and $\mathrm{CO}$ are both 28 , it can be deduced from the above reaction that 2 tonnes of $\mathrm{CO}$ is emitted per tonne of silicon produced. If fossil fuels are used to increase the temperature of the furnace to $1400^{\circ} \mathrm{C}$, then the carbon emissions per tonne of silicon produced would further increase. Lifecycle assessment studies found the global warming potential of solar-photovoltaic electricity to vary in the range of 5 to $16 \mathrm{~kg} \mathrm{CO}_{2}$ eq. per giga joule of electricity produced (Jacobson, 2009), which is equivalent to 6-20\% of the global warming potential of low-sulphur diesel, reported in Table 1.

Cadmium telluride is the second most used photovoltaic material and is preferred owing to its low cost of production. China is planning to use it in its $2000 \mathrm{MW}$ planned solar power station. Cadmium and cadmium compounds are, however, known for their toxicity (Morgan et al., 1995). Tellurium is among the rarest elements in the Earth's crust, the availability of which may define the upper ceiling of cadmium telluridebased solar-photovoltaic electricity production.

The other lauded renewable energy source is wind, which has very low lifecycle global warming potential, amounting to $0.7-2 \mathrm{~kg} \mathrm{CO}_{2}$ equivalent per giga joule of electricity produced (Jacobson, 2009). Environmental and social impacts of wind energy are (Moriarty and Honnery, 2012) bird and bat deaths, possible habitat loss for other wildlife, noise and vibration pollution for nearby residents, adverse effects on visual amenity, possible adverse effects on marine mammals from offshore wind farms and possible climate changes for large-scale implementation. Added to this conventional list is the energy requirement and environmental degradation associated with the use of energy critical element neodymium which is essential in new wind turbine magnets.

Ren (2010) points out, because of the thermal inertia of the oceans and of the vast investments in fossil fuel infrastructure, it is most likely that the $\mathrm{CO}_{2}$ concentrations in the atmosphere and hence the global average surface temperature will continue to rise for some time. Under this scenario, it is likely that a significant decrease in the temperature difference between the polar regions and lower latitudes occurs, which in turn causes reduced wind speeds, thus reduced wind power potential. Ren (2010) has predicted a 14\% reduction in available wind power production in China by 2100 for a mild future greenhouse gas emissions scenario and cautions that strong emission scenarios would cause more severe reductions in available wind resources. It is therefore, highly improbable that the climate-change-proof global archive in $A S$ could be powered by the wind turbines installed on its roof, as portrayed.

From the renewable energy perspective, it would be informative to take a close look at the projections made by the U.S. Energy Information Administration (2016) about the future global energy demand (Figure 1) and the future global electricity demand (Figure 2) under Business-As-Usual scenario.

Figure 1 depicts that energy sources other than fossil fuel and nuclear would contribute much less than $20 \%$ of the global energy demand for a long time to come. Figure 2 depicts that if we take away the conventional hydroelectric power, then renewable energy sources such as wind, solar and other would not even measure up to $15 \%$ of the total future global electricity demand. The reason is, perhaps, the mammoth energy cravings 


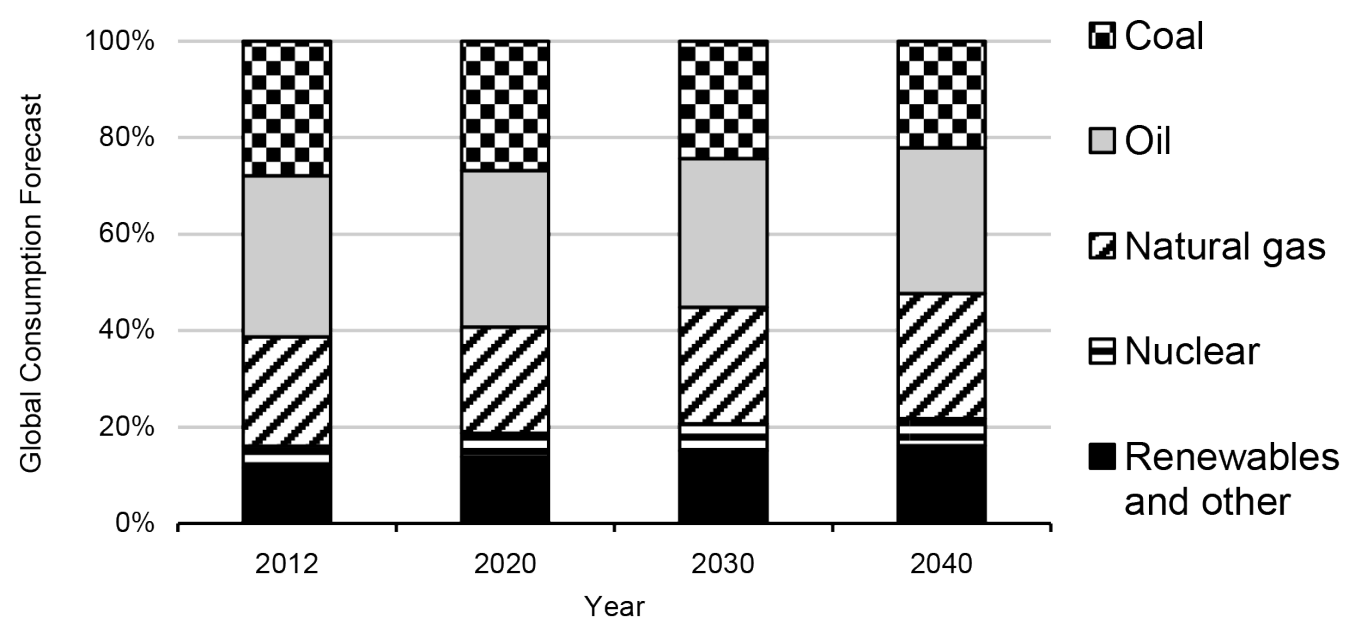

Figure 1: Projection of energy consumption by fuel Source: U.S. Energy Information Administration (2016)

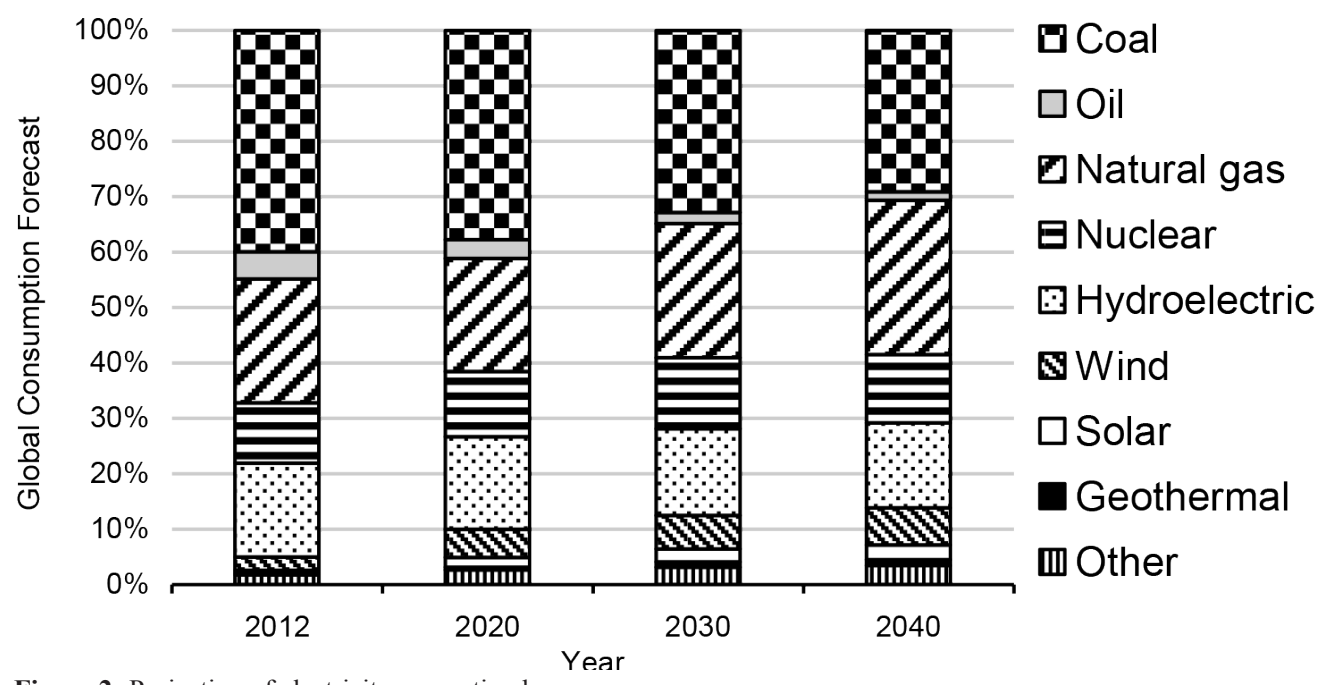

Figure 2: Projection of electricity generation by energy source

Source: U.S. Energy Information Administration (2016)

of the human specie could not be entirely satisfied by the dilute energy content of renewable energy sources. Besides, hoisting the present insignificant contribution of renewable energy in the energy mix to $100 \%$ could take considerable time and, as discussed in all four movies, we do not have just that.

\section{Energy efficiency factor}

It was as early as in 1865 , the economist William Stanley Jevons observed the following:

"The ultimate improvement of the air-engine will probably reduce the consumption [of coal] to less than one-third of the present consumption.... But such an improvement of the engine, when effected, will only accelerate anew the consumption of coal" (Jevons, 1866).
In the holistic view of economists, as opposed to the birdeye view of technologists, energy efficiency improvements encourage enhanced use of the services concerned, thus resulting in increased fuel consumption. This phenomenon is known as Jevons paradox (Blake, 2005) or 'rebound effect' (Grubb, 1990). When the rebound effects are large enough to result in a cumulative increase in the overall initial energy consumption, it is known as 'backfire' (Sorrell, 2007).

In a comprehensive report covering 96 published journal articles on rebound and backfire, Jenkins et al. (2011) state the following:

"Relying on a linear, direct, and one to one relationship between below-cost energy efficiency improvements and carbon emission reductions, as is almost universally the case in contemporary 
policymaking, is very likely to lead nations and the world on a dangerous path. Efforts to reliably reduce greenhouse gas emissions or dependence on depleting fossil fuels would be prudent to avoid the risk of over reliance on energy efficiency measures" (Jenkins et al., 2011).

\section{Energy critical elements (rare earth metals)}

Energy efficient and low carbon technologies, known also as 'green' technologies, include hybrid vehicles, electric vehicles, catalytic converters, compact fluorescent light bulbs, light-emitting diodes, solar photovoltaic cells, fuel cells, rechargeable batteries and efficient wind turbine generators. Successful implementation of these technologies depend heavily upon the availability of elements known as energy critical elements or rare earth metals. For instance, $300 \mathrm{~kg}$ of neodymium, a rare earth metal, is required for a $2 \mathrm{GW}$ wind turbine (Biello, 2010). Neodymium is used in high-strength neodymium magnets used in microphones, professional loudspeakers, in-ear headphones and computer hard disks, in electric motors and generators and in many other modern-day applications.

In rare earths ores, chemically similar metals are found together along with radioactive elements such as radium, thorium and even uranium. Separation of a chosen rare earth metal from its ore, requiring huge amounts of strong acids and strong bases, is an energy-intensive, ecosystemdamaging affair (APS and MRS, 2011; Biello, 2010; Levkowitz and Beauchamp-Mustafaga, 2010; Parry and Douglas, 2011).

Shanthini (2012) has pointed out that humans' attempt to invade the fictional planet Pandora, as portrayed in the blockbuster movie Avatar (Cameron, 2009), is for the fictional element unobtanium. In Avatar, Shanthini (2012) continues, the human race survives the anticipated climate change catastrophe, but is faced with a crisis of depletion of essential metals owing to, perhaps, the extensive use of 'green' technologies.

\section{Carbon capture and sequestration (CCS)}

In $\mathrm{CCS}$, the global warming culprit $\mathrm{CO}_{2}$ emitted at the power plants are captured and stored in underground geological storages such as depleted oil fields, where it is supposed to stay trapped. Availability of CCS technology justifies the continual production of fossil fuel-based electricity, as projected in Figure 2. Al Gore proposes, in $I T$, CCS as one of the viable means to combat global warming.

The first commercial scale application of CCS in the world commenced in 2000. $\mathrm{CO}_{2}$ from the coal gasification plant located in North Dakota, USA, is transported by a $320 \mathrm{~km}$ pipeline to the enhanced oil recovery operations in Weyburn oil field in Saskatchewan, Canada, where it is injected into the depleting oil fields for geological storage. By July 2010, about 18 millions metric tons of man-made $\mathrm{CO}_{2}$ have been stored $1.5 \mathrm{~km}$ underground in a depleted oil reservoir (MIT, 2011).

Lafleur (2010) of Petro-Find Geochem Ltd. investigated into a reported incident of $\mathrm{CO}_{2}$ leakage on Kerr family's property situated above the Weyburn storage site and concluded that the source of the high concentrations of $\mathrm{CO}_{2}$ in soils of the Kerr property is clearly the anthropogenic $\mathrm{CO}_{2}$ injected into the Weyburn reservoir. Petroleum Technology Research Centre (2011) has refuted Lafleur's finding by stating the following:

"The phenomena observed at the Kerr property can be explained by near surface processes including microbial generation of soil $\mathrm{CO}_{2}$ and methane."

Whether or not the $\mathrm{CO}_{2}$ on Kerr's property comes from Weyburn reservoir or soil micro-organisms, leakage of $\mathrm{CO}_{2}$ from the geological storage is a real possibility, and if occurred, it would defy the purpose of storing $\mathrm{CO}_{2}$ in the first place. To assure the robustness of CCS technology, detailed and costly geological surveys of the $\mathrm{CO}_{2}$ burial sites have become pre-requite. A great number of power plants around the world, however, would neither have a geological storage structure to bury $\mathrm{CO}_{2}$, nor the funds required to carry out a costly geological survey. Besides, CCS technology is indeed a bigger-than-human-scale technology, which $\mathrm{Al}$ Gore identifies, in $I T$, as being one of the three causes for the present collision between our civilisation and the earth. (The other two are the population and its way of thinking, according to $\mathrm{Al}$ Gore.)

\section{HYPOCRISY AND DILEMMA EMBEDDED IN} THE MOVIES

\section{Lisa Guy of England says in $A S$,}

"Other than setting fire to a forest, flying is the single worst thing an ordinary individual can do to cause climate change."

Ironically perhaps, the number of flights required by the production and promotion of $A S$ amounted to 57, totalling over 200,000 miles and amounting to the release of over 100 tonnes $\mathrm{CO}_{2}$ equivalent, according to the Spanner Films website (Spanner Films, [online]). The said website features the following: 
"Climate change is a win/lose game - either we keep the planet habitable for human life or we don't... So if our film [AS] contributes to the answer turning out to be "yes", then our 150odd tonnes $\left[\mathrm{CO}_{2}\right.$ pumped into the atmosphere in making and distributing AS] were well worth it. If it doesn't, then all our emissions will have hastened the apocalypse one step nearer."

The above is a display of the dilemma faced by ecoconscious humans.

Prof. Hall in DAT flies to the polar regions to collect samples of ice cores, to India for an apparently useless conference (in the words of the other fictional dedicated scientist in $D A T$, Prof. Terry Rapson), and back to the safety of the US consulate in Mexico. His son flies to Manhattan only because he is courting a girl, which Prof. Hall and his wife highly approve of. Prof. Hall, thereby, portrays a typical human in these trying times. Despite Prof. Hall being the one and only person, according to $D A T$, who has the total scientific knowledge about the oncoming peril due to fossil fuel burning, his carbon footprint laden lifestyle may not be very different from another human who has absolutely no knowledge of the oncoming perils of climate change. Prof. Hall in $D A T$ therefore, could be said as leading a hypocritical lifestyle.

In Becker's inaugural Presidential address portrayed in $D A T$, he says:

"This past few weeks have left us all with a profound sense of humility in the face of nature's destructive power. For years we operated under the belief that we could continue consuming our planet's natural resources without consequence. We were wrong. I was wrong."

By the above statements, I presume, Becker means that our planet's natural resources, fossil fuel, in particular, should be consumed with responsibility.

Becker, however, continues as follows:

"Today there is cause for hope. Only a few hours ago I received word that a small group of people survived in New York City against all odds and in the face of tremendous adversity. I have ordered immediate search and rescue mission to bring them home and to look for more survivors."

Here, Becker contradicts himself and patronises the usual resource-intensive, in particular, fossil fuel-intensive lifestyles of the masses, rather, for the masses.
Black Hawk helicopters that went on the search and rescue missions in $D A T$ are four-bladed twin engine helicopters powered by gas turbine engines fuelled by fossil fuels. The transport efficiency of a Black Hawk is as little as 0.2 to $0.3 \mathrm{~km}$ per litre of fuel burnt (The Black Hawk [online]). Moreover, gas turbine is a heat engine which converts heat energy trapped in the fossil fuels into work energy. Any heat engine is inherently inefficient according to the Second Law of Thermodynamics (McKay, 2009; Schmitz, 2007; Shanthini, 2009). In case of the gas turbine fitted in a helicopter, it could convert much less than $25 \%$ of the energy available in the fossil fuel into the work needed to fly it (Nkoi et al., 2013). The remaining energy content of the fossil fuel burnt in the gas turbine engine is simply wasted making it unavailable for anyone or anything else. The thermal efficiency that a gas turbine could achieve in real life situations is bounded by a delusional maximum of $60 \%$, which is realised when the heat from the gas turbine exhaust is effectively utilised by a steam turbine in a electricity production system, known as combined cycle power plant (Physorg [online]).

Al Gore says in IT that he travelled to the South Pole, the North Pole, the Amazon and other places where scientists helped him " "understand issues that he did not really understand in depth". He then travelled to more than thousand places, and may still be travelling, to give his slide show presentations to make many more people understand what he understood. In consideration of the dire consequences of climate change, Al Gore finds it perfectly justifiable to be burning so much of fossil fuels in his flights on jets (as shown many times in IT) to 'go city by city, person by person and family by family to change enough mind to cross a threshold'. However, he appeals to the masses to strive hard to achieve zero emissions in their personal lives.

While Alvin DuVernay of New Orleans says, in $A S$, that we have not been very smart about how we use our resources, Jehangir Wadia of India founded a budget airline, GoAir, for the masses to afford air travel, and thereby, plunging India deep into high carbon economy while improving his company's business turnover. The World Economic Forum has honoured Jehangir Wadia by naming him as one of the Young Global Leaders 2008 (Hindustan Times, 2008), partly in recognition of his commitment to society and his potential to contribute to shaping the future of the world.

The above mentioned choices between the responsible consumption of natural resources, fossil fuel in this case, and undertaking inevitable missions at any cost is a dilemma that the human race have to continue to face. The crucial question here is who will decide what is an 
inevitable mission requiring the inefficient use of fossil fuels and what is not.

\section{ROLE OF HUMANITY IN ECOSYSTEM RESTORATION}

Having scrutinised the limitations, the hypocrisy, and the dilemma embedded in the technological solutions to climate change suggested in the movies considered, let us now focus on the plausible role of humanity in restoring the health of Mother Earth.

\section{Humanity as dealt with in the movies considered}

When it comes to dealing with humanity as opposed to human, $D A T$ is a complete failure. Its characters are heroic and superficial. Even those who have change of hearts during the span of the movie, such as Becker, underwent stereotypical transformations. Incidentally, DAT ends with an astronaut in an orbiting satellite looking out and asking the other, "Have you ever seen the air so clear?" It implies, I guess, that the pollutants in air have been pulled all the way down by the superstorms, and buried under the fresh snow cover. It is CCS indeed. The difference is, it is Mother Nature who has helped solving the climate change crisis. She has done it without wiping out the human race, its military might and its governments. In doing so, of course, she has killed millions of people (and other living things). DAT is just a typical American disaster movie with a happy ending of reverting back to the same old values, enriched by special effects.

$I T$ is unable to distil the inner human values from responsible consumerism. For instance, Al Gore says in IT,

\begin{abstract}
"Each one of us is a cause of global warming but each one of us can make choices to change that. With the things we buy, the electricity we use, the cars we drive. We can make choice to bring our individual carbon emissions to zero. The solutions are in our hands. We just have to have the determination to make them happen."
\end{abstract}

$\mathrm{Al}$ Gore's inability to see the impossibility of bringing down an individual's carbon emissions to zero goes hand in hand with his inability to see humanity being way above green consumers, and green producers.

$11 \mathrm{H}$ deals amply on the role of humanity in ecosystems restorations. Ecologist Peter Warshall states in $11 \mathrm{H}$ that the world could perhaps be saved by kindness, big heart, and the passion for the place one lives in. Other similar sentiments expressed in $11 \mathrm{H}$ are as follows: treating all lives with great humility and respect, justice and fairness; love being the force that makes us fully human; disengaging from consumerism as the main avenue of experience; prioritising quality time for oneself over long commute, bigger car and bigger house; embracing frugality (meaning wise use of limited resources).

$A S$ dedicatedly follows the life of Alvin DuVernay of New Orleans, whose post-Katrina life, according to Alvin DuVernay himself, is slim on consumerism. Saving lives during the devastation of Katrina appears to have enlightened him on the fact that the main avenue of experience in life need not be consumerism. This simple, though difficult to grasp, fact is elaborated in the delightful French movie Amélie, which has received both critical acclaim and box-office success.

\section{Humanity as dealt with in Amélie}

Amélie touches the hearts of people those who watch it by its central theme, which is the joy of life's simple pleasures. The lead character, named Amélie, is a naive young girl leading a very ordinary life. She has cultivated a taste for simple pleasures, such as dipping her hand into sacks of grain and skipping stones at a canal. She accidentally finds a box which was hidden by a boy decades ago in her apartment. The box is full of very ordinary things that are of value only to its owner. She searches for him, finds him and returns the box without disclosing her identity. She witnesses how touched the owner is by that rare gift, which has absolutely no monetary value. She walks away from the scene, and the background voice describes her state of mind as follows:

"Amélie has a strange feeling of absolute harmony. It is a perfect moment. Soft light. A scent in the air. The quiet murmur of the city. She breathes deeply. Life is simple and clear. A surge of love, an urge to help mankind comes over her."

The rest of the movie is about how Amélie continues in her mission to silently enrich the lives of other people around her, despite her isolated life. Each episode is deceivingly simple and delightfully touchy. As a matter of fact, there is a scene in Amélie which could be seen as ridiculing the carbon-intensive lifestyles. The shop keeper's aide Lucien tells the artist Dufayel,

"I heard there'll soon be a new star... In America, they'll take rich people's ashes, put them in a satellite, and shoot it into space. It's going to shine forever."

Movies like Amélie works subtly through the use of humor on our consciousness. Such movies have the 
power to kindle the emotional fire needed to purify our heart to see the true pleasures of life, outside egocentrism.

\section{Humanity as means for ecosystem restoration}

Even though Amélie succeeds in its portrayal of denouncing egocentrism, it is unable to work itself out of human-centrism and is completely oblivious to the ills of human-centrism or it is not so subtle contribution towards ecosystem deterioration. Human-centrism, according to Paolo Soleri of $11 \mathrm{H}$, is moulded in greed and in opportunism. Greed, according to Kenny Ausubel of $11 \mathrm{H}$, is built into corporate economic globalisation. As our lifestyles and values nowadays, more than ever, have been completely dictated by corporate economic globalisation, it appears that even the so-called freedom of citizens of the democratic nations only allow us restricted deviations from the consumerism-led lifestyles for which we willingly offer free servitude.

Moreover, the success of corporate economic globalisation requires money-earners and money-losers. Even though, in an ideal economy, there would be no dividing line between the two, in reality the two groups are polarised. Economic polarisation is present within communities, within cities, within nations and within the world. As we may expect, persistent existence of economic polarisation simply means lack of compassion, and hence humanity, among humans. Such a state of affair is detrimental for collective decisions demanded for arresting global warming.

The future of the world may be that in which the abovementioned state of affairs continues with marketled incremental changes brought upon the system purely by incremental policy changes dictated by resource depletion. If it would be so then, as Raskin et al. (2002) of the Global Scenario Group argue, we may enter a future that the pessimistic Barbarization Scenario holds. Raskin et al. (2002) paint a very gloomy picture of two variants of Barbarization Scenario: Breakdown and Fortress World, and continues as follows:

"In Breakdown, conflict and crises spiral out of control and institutions collapse. Fortress World features an authoritarian response to the threat of breakdown, as the world divides into a kind of global apartheid with the elite in interconnected, protected enclaves and an impoverished majority outside."

Such a disturbing future may be avoided if the humans are taken out of human-centrism and are aided to develop compassion towards other humans and non-human beings, in the sense of Immanual Kant ${ }^{1}$ (1724-1804).
In line with the writings in the volumes edited by Giri (2015) and, Mackenzie and Posthumus (2015), and with the author's own experiences of adopting stray animals in the verge of death (Shanthini, 2015), it may be proposed that the humans share their physical and emotional space with animals, as portrayed in the delightful Disney-Pixar 2007 movie Ratatouille (Bird, 2007). Even there, alas, one could not escape human-centrism, as the elevated, metaphorically and literally, space provided to the rat community has everything to do with the human gains than animal dignity. Animals as a mere use of human needs has its origins in René Descartes (1596-1650) view that nonhuman animals can be viewed as no more than machines with parts assembled in intricate ways and that the presence of a thinking soul in animals can't be proven (Descartes, 1993). This philosophy, with its base on the concept of soul, has alienated human's emotional engagement from not only animals and nature, but also from fellow humans.

What is required at present is a search for human happiness and fulfillment which could definitely be brought about by developing compassion towards all living-beings and nonliving-beings with the full acceptance of their right to dignity and existence. Raskin et al. (2002) of the Global Scenario Group point out that such happiness and fulfillment may lead all of us into a romantic future that the Great Transition Scenario holds. Raskin et al. (2002) continue that all what we must do

"....is to make good on the commitments in the 1948 Universal Declaration on Human Rights to justice and a decent standard of living for all, in the context of a plural and equitable global development model".

\section{CONCLUSION}

The movies dealing with climate change and other biosphere crisis have the responsibility to go all the way in scrutinising the solutions that they propose. As demonstrated in this paper, there is an ample volume of peer-reviewed journal publications already available which could tell us how sustainable are the seemingly sustainable energy technologies. In devoid of such information, the movies may lull the viewer into a state of complacency over the technological capacity of the human race to overcome any crisis.

Moreover, movies such as Amélie certainly brings to the surface that "disengaging from consumerism as the main avenue of experience" could bring about happiness in oneself. It is a theme that ought to be dealt with in the tales of sustainability told by the movie industry. It is true that individualised efforts would make a grand 
contribution towards taking all of us towards a sustainable world, provided such efforts are not just materialistic but mingled with the sense of treating every other living being with justice and fairness.

\section{END NOTES}

1. If he is not to stifle his human feelings, he must practice kindness towards animals, for he who is cruel to animals becomes hard also in his dealings with men. We can judge the heart of a man by his treatment of animals (Golden and Kilroe, 1997).

\section{REFERENCES}

Adam, D. (2007) Gore's climate film has scientific errors judge. The Guardian. [Online] 11th October 2007. Available from: https://www.theguardian.com/environment/2007/oct/11/ climatechange [Accessed: $15^{\text {th }}$ December 2014].

American Physical Society \& Materials Research Society (2011) Energy critical elements: securing materials for emerging technologies. [Online] Available from: http://www. aps.org/policy/reports/popa-reports/upload/elementsreport.pdf [Accessed: 15 ${ }^{\text {th }}$ December 2014].

Arrhenius, S. (1896) On the influence of carbonic acid in the air upon the temperature of the ground. Philosophical Magazine and Journal of Science. 41. pp: 237-276. [Online] Available from: http://www.rsc.org/images/Arrhenius1896_tcm18-173546.pdf [Accessed: 23 ${ }^{\text {rd }}$ September 2015].

Benyus, J. M. (2002) Biomimicry: innovation inspired by nature. New York: Perennial (an imprint of HarperCollins Publishers Inc.).

Biello, D. (2010) Rare earths: elemental need of the clean-energy economy. Scientific American. [Online] Available from: http:// www.scientificamerican.com/article/rare-earths-elemental-needsof-the-clean-energy-economy/ [Accessed: 14 ${ }^{\text {th }}$ November 2014].

Bird, B. (2007) Ratatouille. [Online] Available from: https:// en.wikipedia.org/wiki/Ratatouille_\%28film\%29 [Accessed: $23^{\text {rd }}$ September 2015].

Blake, A. (2005) Jevons' paradox. Ecological Economics. 54(1). pp: 9-21.

DOI: http://dx.doi.org/10.1016/j.ecolecon.2005.03.020

Cameron, J. (2009) Avatar. [Online] Available from: https:// en.wikipedia.org/wiki/Avatar_(2009_film) [Accessed: $13^{\text {th }}$ February 2014].

Descartes, R. (1993) Animals are Machines. In: S.J. Armstrong \& R.G. Botzler (eds). Environmental Ethics: Divergence and Convergence. New York: McGraw-Hill. pp: 281-285.
Dominguez-Faus, R., Powers, S. E., Burken, J. G. \& Alvarez, P. J. (2009) The water footprint of biofuels: a drink or drive issue? Environmental Science \& Technology. 43. pp: 3005-3010.

DOI: http://dx.doi.org/10.1021/es802162x

Dufour, J. \& Iribarren, D. (2012) Life cycle assessment of biodiesel production from free fatty acid-rich wastes. Renewable Energy. 38(1). pp: 155-162.

DOI: http://dx.doi.org/10.1016/j.renene.2011.07.016

Durant, R. F. \& Legge, J. S. Jr. (2005) Public opinion, risk perceptions, and genetically modified food regulatory policy. European Union Politics. 6(2), pp: 181-200.

DOI: http://dx.doi.org/10.1177/1465116505051982

Earth System Research Laboratory (2015) CO2 CCGG (Individual Flasks). [Online] Available from: ftp://aftp.cmdl. noaa.gov/data/trace_gases/co2/flask/surface/co2_mlo_surfaceflask_1_ccgg_month.txt [Accessed: $30^{\text {th }}$ September 2015].

Emmerich, R. (2004) The Day After Tomorrow. [Online] Available from: https://en.wikipedia.org/wiki/The_Day_After_ Tomorrow [Accessed: $10^{\text {th }}$ November 2014].

Evans, G. \& Durant, J. (1995) The relationship between knowledge and attitudes in the public understanding of science in Britain. Public Understanding of Science. 4(1). pp: 57-74. DOI: http://dx.doi.org/10.1088/0963-6625/4/1/004

Fraiture, C. de, Giordano, M. \& Liao, Y. (2008) Biofuels and implications for agricultural water use: blue impacts on green energy. Water Policy. 10 (Suppl 1). pp: 67-81.

DOI: http://dx.doi.org/10.2166/wp.2008.054

Giri, A. K. (2015) New horizons of human development. New Delhi: Studera Press.

Graedel, T. E. \& Allenby, B. R. (2003) Industrial Ecology. Englewood Cliffs. New Jersey: Prentice Hall.

Grubb, M. J. (1990) Energy efficiency and economic fallacies. Energy Policy. 18. pp: 783-785.

DOI: http://dx.doi.org/10.1016/0301-4215(90)90031-X

Guggenheim, D. (2006) An Inconvenient Truth. [online] Available from: https://en.wikipedia.org/wiki/An Inconvenient_Truth [Accessed: 10th November 2014].

Hansen. J., Sato, M., Kharecha, P., Beerling, D., Berner, R., Masson-Delmotte, V., Pagani, M., Raymo, M., Royer, D. L. \& Zachos, J. C. (2008) Target atmospheric $\mathrm{CO}_{2}$ : where should humanity aim?. The Open Atmospheric Science Journal. 2. pp: 217-231.

DOI: http://dx.doi.org/10.2174/1874282300802010217

Hindustan Times. (2008) 17 Indians among WEF young global leaders. Hindustan Times. [Online] 12th March. Available from: http://www.hindustantimes.com/business/17-indians-amongwef-young-global-leaders/story-8xX01V2ewPYzw919BjQkvI. html [Accessed: $15^{\text {th }}$ February 2015]. 
Intergovernmental Panel on Climate Change (2007) Climate change 2007: synthesis report. [Online] Available from: http:// www.ipcc.ch/publications_and_data/publications_and_data_ reports.shtml [Accessed: $29^{\text {th }}$ September 2015].

Jacobson, M. Z. (2009) Review of solutions to global warming, air pollution and energy security. Energy \& Environmental Science. 2. pp: 148-173.

DOI: http://dx.doi.org/10.1039/B809990C

Jenkins, J., Nordhaus, T. \& Shellenberger, M. (2011) Energy emergence: rebound and backfire as emergent phenomena. Breakthrough Institute [Online] Available from: http:// thebreakthrough.org/blog/Energy_Emergence.pdf [Accessed: $15^{\text {th }}$ February 2015]

Jeunet, J. P. (2001) Amélie. [Online] Available from: https:// en.wikipedia.org/wiki/Am\%C3\%A9lie [Accessed: $13^{\text {th }}$ January 2015].

Jevons, W. S. (1866) The coal question: an inquiry concerning the progress of the nation and the probable exhaustion of our coal mines. 2nd edition. London: Macmillan \& Co. [Online] Available from: oilcrash.net/media/pdf/The_Coal_Question. pdf [Accessed: $30^{\text {th }}$ September 2015]

Kant, I. (1997) Lectures on ethics: duties toward animals and spirits. In O. Golden \& P. Kilroe (eds.). Human Life and the natural world Readings in the history of western philosophy. Canada: Broadview Press Ltd. pp: 152-153.

DOI: http://dx.doi.org/10.1017/cbo9781107049512

Kellstedt, P. M., Zahran, S. \& Vedlitz, A. (2008) Personal efficacy, the information environment and attitudes toward global warming and climate change in the United States. Risk Analysis. 28(1). pp: 113-126.

DOI: http://dx.doi.org/10.1111/j.1539-6924.2008.01010.x

Kunstler, J. H. (2005) The long emergency: surviving the converging catastrophes of the Twenty-first Century. New York: Atlantic Monthly Press.

Lafleur, P. (2010) Geochemical soil gas survey: a site investigation of SW30-5-13-W2M, Weyburn Field, Saskatchewan. [Online] Available from: http://www. gasoilgeochem.com/reportcameron $\% 20$ jane\%20kerr.pdf [Accessed: 12 ${ }^{\text {th }}$ November 2014].

Levkowitz, L. \& Beauchamp-Mustafaga, N. (2010) China's rare earths industry and its role in the international market. U.S.-China Economic and Security Review Commission. [Online] Available from: http://www.uscc.gov/Research/ china $\%$ E2\%80\%99s-rare-earths-industry-and-its-roleinternational-market [Accessed: $15^{\text {th }}$ February 2012].

Mackenzie, L. \& Posthumus, S. (2015) French thinking about animals. Michigan: Michigan State University Press.

Massachusetts Institute of Technology (2011) Weyburn fact sheet: carbon dioxide capture and storage project. [Online]
Available from: http://sequestration.mit.edu/tools/projects/ weyburn.html [Accessed: $15^{\text {th }}$ December 2014].

McDonough, W. \& Braungart, M. (2002) Cradle to cradle: remaking the way we make things. New York: North Point Press.

McKay, D. J. C. (2009) Sustainable energy - without the hot air. UIT Cambridge Ltd., England. [Online] Available from: http://www.inference.phy.cam.ac.uk/sustainable/book/tex/ sewtha.pdf [Accessed: $15^{\text {th }}$ December 2014].

Morgan, D. L., Shines, C. J., Jeter, S. P., Wilson, R. E., Elwell, M. P., Price, H. C. \& Moskowitz, P. D. (1995) Acute pulmonary toxicity of copper gallium diselenide, copper indium diselenide and cadmium telluride intratracheally instilled into rats. Environmental Research. 71(1). pp: 16-24.

DOI: http://dx.doi.org/10.1006/enrs.1995.1062

Moriarty, P. \& Honnery, D. (2012) What is the global potential for renewable energy?. Renewable and Sustainable Energy Reviews. 16. pp: 244-252.

DOI: http://dx.doi.org/10.1016/j.rser.2011.07.151

Mumovic, D. \& Santamouris, M. (2009) A handbook of sustainable bundling design \& engineering: an intergarted approach to energy, health and operational performance. UK and USA: Earthscan.

Nkoi, B., Pilidis, P. \& Nikolaidis, T. (2013) Performance of small-scale aero-derivative industrial gas turbines derived from helicopter engines. Propulsion and Power Research. 2(4). pp: 243-253.

DOI: http://dx.doi.org/10.1016/j.jppr.2013.11.001

Parry, S. \& Douglas, E. (2011) In China, the true cost of Britan's clean, green wind power experiment: pollution on a disastrous scale. Mail Online. [Online] $26^{\text {th }}$ January 2011, Available from: http://www.dailymail.co.uk/home/moslive/article-1350811/InChina-true-cost-Britains-clean-green-wind-power-experimentPollution-disastrous-scale.html [Accessed: 21 ${ }^{\text {st }}$ November 2014].

Petersen, L. C. \& Conners, N. (2007) The $11^{\text {th }}$ Hour. [Online] Available from: https://freedocumentaries.org/documentary/ the-11th-hour [Accessed: $10^{\text {th }}$ November 2014].

Petroleum Technology Research Centre (2011) IEAGHG Weyburn-Midale CO2 Monitoring \& Storage Project: Response to the Petro-Find Geochem Ltd. Study. [Online] Available from: ptrc.ca/+pub/document/WMP-Response-to-Petro-Find. pdf [Accessed: $10^{\text {th }}$ February 2012].

Physorg (2011) [Online] Efficiency record of combined cycle power plant. 24th March 2011, Available from: http://phys.org/ news/2011-05-efficiency-combined-power.html [Accessed: $15^{\text {th }}$ February 2015].

Raskin, P., Banuri, T., Gallopín, G., Gutman, P., Hammond, Al., Kates, R. \& Swart, R. (2002) Great transition: the promise 
and lure of the times ahead (A report of the Global Scenario Group). Boston: Stockholm Environment Institute.

Ren, D. (2010) Effects of global warming on wind energy availability. Journal of Renewable and Sustainable Energy. 2(5). 052301.

DOI: http://dx.doi.org/10.1063/1.3486072

Schmitz, J. E. J. (2007) The second law of life: energy, technology and the future of earth as we know it. New York: William Andrew Publishing.

Shanthini, R. (2009) Thermodynamics for beginners. Peradeniya, Sri Lanka: Science Education Unit, University Peradeniya. [Online] Available from: http://www.rshanthini. com/ThermoBook.htm [Accessed: $15^{\text {th }}$ November 2014].

Shanthini, R. (2012) Did Rio+20 assure a sustainable future? Economic Review. June/July 2012. Colombo: People's Bank. pp: 39-43.

Shanthini, R. (2015) Suffering, solidarity and joy: the story of Maggie. In: A. K. Giri. (ed.). New Horizons of Human Development. New Delhi: Studera Press. pp: 475-480.

Sorrell, S. (2007) The rebound effect: an assessment of the evidence for economy-wide energy savings from improved energy efficiency. UK: Energy Research Centre. [Online] Available from: http://www.ukerc.ac.uk/Downloads/F/07/0710 ReboundEffect/0710ReboundEffectReport.pdf [Accessed: $15^{\text {th }}$ February 2015].

Spanner Films. Carbon footprint [Online] Available from: http://www.spannerfilms.net/carbon_footprint [Accessed: $15^{\text {th }}$ February 2015].

Stasinopoulos, P., Smith, M. H., Hargroves, K. C. \& Desha, C. (2009) Whole system design: an integrated approach to sustainable engineering. UK and USA: Earthscan.
The Black Hawk. [Online] Available from: https://www. aircraftcompare.com/helicopter-airplane/sikorsky-uh-60-mblack-hawk/235 [Accessed: $31^{\text {st }}$ August 2016].

Timilsina, G. R., Kurdgelashvili, L. \& Narbel, P. A. (2012) Solar energy: markets, economics and policies. Renewable and Sustainable Energy Reviews. 16. pp: 449-465.

DOI: http://dx.doi.org/10.1016/j.rser.2011.08.009

U. S. Department of Energy (2006) Energy demands on water resources: report to congress on the interdependency of energy and water. Washington, DC: U.S. Department of Energy.

U.S. Energy Information Administration (2016) International Energy Outlook 2016. [Online] Available from: http://www.eia. gov/forecasts/ieo/ [Accessed: $31^{\text {st }}$ August 2016].

\section{Films:}

Amélie. (2001) Film. Directed by Jean-Pierre Jeunet. France: Claudie Ossard Productions.

An Inconvenient Truth. (2006) Film. Directed by Davis Guggenheim. USA: Lawrence Bender Productions \& Participant Media.

Avatar. (2009) Film. Directed by James Cameron. USA: Twentieth Century Fox Film Corporation.

Ratatouille. (2007) Film. Directed by Brad Bird \& Jan Pinkava. USA: Pixar Animationa Studios \& Walt Disney Pictures.

The $11^{\text {th }}$ Hour. (2007) Film. Directed by Leila Conners Petersen \& Nadia Conners. USA: Appian Way, Greenhour \& Tree Media Group.

The Age of Stupid. (2009) Film. Directed by Franny Amstrong. London: Spanner Films.

The Day After Tomorrow. (2004) Film. Directed by Roland Emmerich. USA: Twentieth Century Fox Film Corporation. 